Article

\title{
Toxic Effects of Thallium on Biological Indicators of Haplic Chernozem Health: A Case Study
}

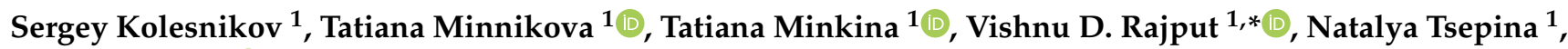 \\ Kamil Kazeev ${ }^{1}{ }^{\circledR}$, Alexander Zhadobin ${ }^{2}$, Elena Nevedomaya ${ }^{1}$, Tigran Ter-Misakyants ${ }^{1}$, Yulia Akimenko ${ }^{1}$, \\ Saglara Mandzhieva ${ }^{1}{ }^{(0)}$, Svetlana Sushkova ${ }^{1}{ }^{\circledR}$, Anuj Ranjan ${ }^{1}$, Ilgiz Asylbaev ${ }^{3}$, Victoria Popova ${ }^{4}$ \\ and Alena Tymoshenko ${ }^{1}$
}

check for updates

Citation: Kolesnikov, S.; Minnikova, T.; Minkina, T.; Rajput, V.D.; Tsepina,

N.; Kazeev, K.; Zhadobin, A.;

Nevedomaya, E.; Ter-Misakyants, T.;

Akimenko, Y.; et al. Toxic Effects of

Thallium on Biological Indicators of Haplic Chernozem Health: A Case Study. Environments 2021, 8, 119. https://doi.org/10.3390/

environments 8110119

Academic Editor: Alfredo Cassano

Received: 15 September 2021

Accepted: 30 October 2021

Published: 3 November 2021

Publisher's Note: MDPI stays neutral with regard to jurisdictional claims in published maps and institutional affiliations.

Copyright: (c) 2021 by the authors. Licensee MDPI, Basel, Switzerland. This article is an open access article distributed under the terms and conditions of the Creative Commons Attribution (CC BY) license (https:/ / creativecommons.org/licenses/by/ $4.0 /)$.
1 Southern Federal University, 344090 Rostov-on-Don, Russia; kolesnikov1970@list.ru (S.K.); loko261008@yandex.ru (T.M.); tminkina@mail.ru (T.M.); cepinanatalia@yandex.ru (N.T.); kamil_kazeev@mail.ru (K.K.); mj20@rambler.ru (E.N.); rak@bk.ru (T.T.-M.); akimenkojuliya@mail.ru (Y.A.); msaglara@mail.ru (S.M.); terra_rossa@mail.ru (S.S.); aranjan@amity.edu (A.R.); aly9215@mail.ru (A.T.)

2 Rostov on Don Zoo, 344039 Rostov-on-Don, Russia; a90981@yandex.ru

3 Soil Science Department, Bashkir State Agrarian University, 450001 Ufa-Bashkortostan, Russia; ilgiz_bsau@mail.ru

4 Rostov Research Institute of Obstetrics and Paediatrics, 344012 Rostov-on-Don, Russia; vait49@mail.ru

* Correspondence: rajput.vishnu@gmail.com

Abstract: Thallium (Tl) was introduced into Haplic Chernozem in the amounts of 3, 30, and $300 \mathrm{mg} / \mathrm{kg}$, and biological indicators were observed at 10, 30, and 90 days after incubation in the laboratory experiment. An increase in biological activities; i.e., the total number of bacteria, Azotobacter spp. abundance, enzymes (catalase, dehydrogenases), and phytotoxic indicators (germination rate of radish) after 30 days of $\mathrm{Tl}$ exposure were noted. The total number of bacteria and Azotobacter spp. abundance, enzyme activity, and phytotoxicity were more sensitive (16-76\%) and informative (12-65\%) indicators compared to the control, respectively. Integral biological indicators of soil state (IIBS) noted at 10, 30, and 90 days decreased at a dose of 30 and $300 \mathrm{mg} / \mathrm{kg}$ by $13-43 \%$ in relation to the control. An increase in $\mathrm{Tl}$ concentration and duration of exposure (up to 90 days) inhibited biological properties and caused ecotoxicological effects, respectively. We concluded that the use of individual indicators served as an indicator of the state of the soil.

Keywords: thallium; pollution; soil; ecotoxicity; biological activity

\section{Introduction}

Chemical contamination of the soil is most often represented by a mixture of substances in inorganic and organic forms (heavy metals, petroleum hydrocarbons and polycyclic aromatic hydrocarbons) [1-3]. Numerous works are devoted to the analysis of the detrimental impacts of coal stations on the biological conditions of soils and ecosystems $[4,5]$. However, not all heavy metals have received comparable attention, and thallium (Tl) is the least explored one. The United States Environmental Protection Agency (US EPA) considers $\mathrm{Tl}$ as a priority role pollutant [6]. The investigations of $\mathrm{Tl}$ have been mainly focused on its content in soils. Priority sources of soil pollution with Tl include: coal combustion at thermal power plants, the operation of cement plants, ferrous and nonferrous metallurgy enterprises, the use of rodenticides, and hydrocarbon oil products [7-9]. The toxic form of $\mathrm{Tl}$ relies on its oxidation state: $\mathrm{Tl}^{3+}$ is more toxic than $\mathrm{Tl}^{2+}[8,10,11]$.

$\mathrm{Tl}$ is present in the soil in very small amounts; i.e., less than $1 \mathrm{mg} / \mathrm{kg}[10,12,13]$, but it is reported to be highly toxic [14-16] even more toxic than $\mathrm{Hg}, \mathrm{Cd}, \mathrm{Pb}, \mathrm{Cu}$, and $\mathrm{Zn}[17,18]$. The range of $\mathrm{Tl}$ detection in areas of pyrite deposits was from 5 to $15 \mathrm{mg} / \mathrm{kg}$, and near sulfide deposits was from 40 to $124 \mathrm{mg} / \mathrm{kg}$ [19-21]. An excess of the background content of $\mathrm{Tl}$ in the soil by hundreds of thousands of times was recorded near coal mines, and 
reached up to $20,000 \mathrm{mg} / \mathrm{kg}$ [22]. Some studies revealed that the content of $\mathrm{Tl}$ can be up to $7-19 \mathrm{mg} / \mathrm{kg}$ in polluted soils $[11,19,23]$. As a result of the accumulation of $\mathrm{Tl}$ in crops, the risk of introducing the element into the food chain is quite significant [24,25]. Horticultural crops can store up to $1100 \mathrm{mg} / \mathrm{kg} \mathrm{Tl} \mathrm{[9].}$

The assessment of the ecotoxicity of potential toxic elements (PTE) can use microbial properties such as active number of bacteria, the activity of enzymes, and phytotoxicity indicators. The total number of bacteria in the soil reflects the state of reducers in the ecosystem [26]. It can be determined by the luminescence microscopy method while considering the number of soil bacteria after staining with acridine orange dye [27]. Acridine orange is a fluorochromatic dye that binds to nucleic acids in bacteria and other cells. Under the influence of ultraviolet radiation, acridine orange stains ribonucleic acid (RNA) and single-stranded DNA in orange (as soil particles), and double-stranded DNA in green (as bacterial cells). Azotobacter spp. abundance traditionally has been used to indicate chemical pollution of soils [28]. Oxidoreductases (as catalase, dehydrogenases, peroxidases, and polyphenoloxidases) are functionally necessary for the decomposition of pollutants, the transformation of organic matter, and the maintenance of the metabolism of microorganisms $[29,30]$. Catalase activity decreases with soil contamination by petroleum hydrocarbons and heavy metals [1,31-33]. The activity of catalase is related to the metabolic activity of aerobic organisms, and is often used as one of the indicators of soil fertility. The phytotoxic properties of soil were analyzed in terms of the intensity of initial seed growth (germination rate) and length of the roots of radish (Raphanus sativus L.) seedlings. Compared to other plant test objects, radish showed a fast response to soil nutrients and moisture [34]. The germination rate and root length of radish were the most informative of the many indicators of soil phytotoxicity [31,35-37]. The use of these biological indicators will open up many opportunities for both cleaning and restoring soil fertility after contamination with various PTEs.

Assessing the effect of $\mathrm{Tl}$ on the state of soils and terrestrial ecosystems, establishing the limits of soil resistance to $\mathrm{Tl}$ pollution, and standardizing the $\mathrm{Tl}$ content in soil are quite urgent tasks. When assessing soil resistance to $\mathrm{Tl}$ pollution, it is advisable to use biological indicators, as in the case of other chemical soil pollutants [26,38]. Thus, the objective of the current work was to evaluate the ecotoxicity of $\mathrm{Tl}$ by using biological indicators of the condition of Haplic Chernozem health as a case study.

\section{Materials and Methods}

\subsection{Soil Sampling and Site Description}

Soil samples were collected from the top layer of Haplic Chernozem from the territory of the Persianovskaya steppe reserve (Rostov region, Russia) [39,40]. The Persianovskaya Steppe Nature Reserve is virgin soil, and the site is listed in the Red Book of Russian Soils [41]. In addition, on the territory of the steppe, many rare plants grow (more than 17 species), such as Túlipa biebersteiniána L. and Bellevalia sarmatica L. Haplic Chernozem was characterized by high soil organic matter $(4.0 \%)$, the neutral reaction of the medium $(\mathrm{pH}=7.6)$, heavy-loamy granulometric composition with high biological activity: total number of soil bacteria $\left(3.5 \times 10^{9}\right.$ per gram of soil dry weight), catalase activity $\left(8.4 \mathrm{~mL} \mathrm{O}_{2}\right.$ in a gram of soil dry weight for $1 \mathrm{~min})$, dehydrogenases activity (14.5 $\mathrm{mg}$ TPF in a gram of soil dry weight for $24 \mathrm{~h}$ ), and Azotobacter spp. abundance (100\% of the fouling lumps).

\subsection{Spiking of Thallium into Haplic Chernozem and Experimental Conditions}

The collected soil was contaminated with $\mathrm{Tl}$ in the form of $\mathrm{Tl}_{2} \mathrm{O}_{3}$ in laboratory conditions. The form of $\mathrm{Tl}^{3+}$ was considered due to it being more toxic than $\mathrm{Tl}^{2+}[42,43]$. Thallium was introduced in the amounts of 3,30 , and $300 \mathrm{mg} / \mathrm{kg}$ in a mortar with a small volume of soil and then thoroughly mixed with the entire volume of soil. After that, water was added to laboratory vessels with $\mathrm{Tl}$ and soil (Figure 1). The use of oxides excluded the influence of accompanying anions on the properties of the soil, which is characteristic of salts of macro- and microelements. The Tl background content in Haplic Chernozem was 
defined by an ELAN-DRC-e inductively coupled plasma mass spectrometry instrument (Perkin Elmer, Inc., Waltham, MA, USA; range $10^{-5}$ to $0.1 \%$ ).

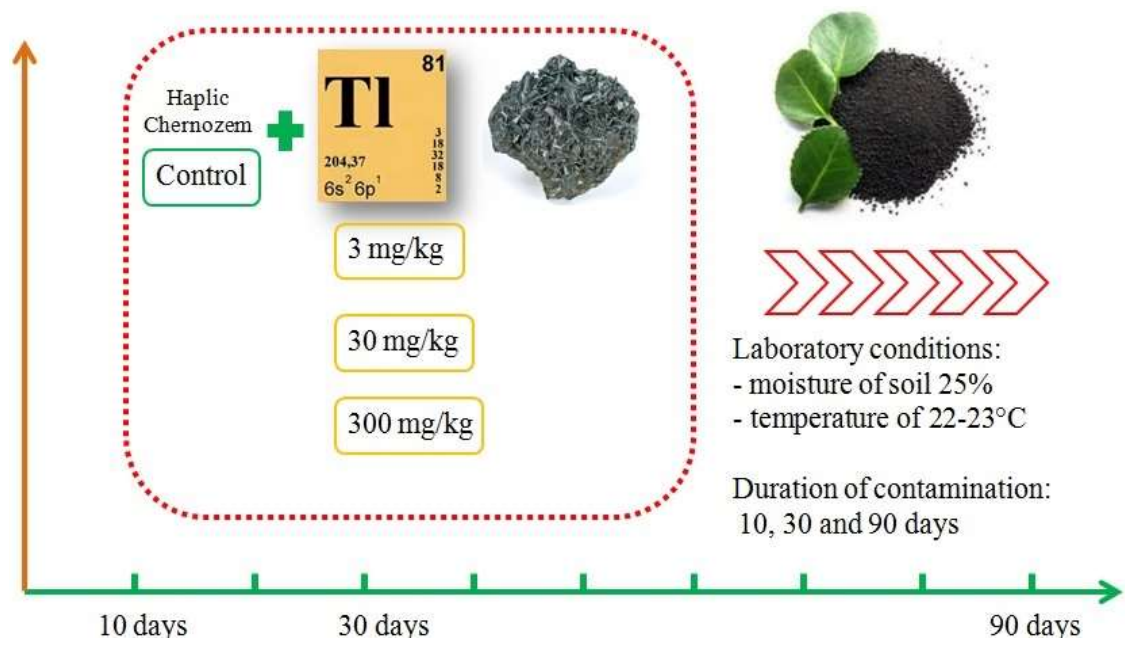

Figure 1. Scheme of experiments under the laboratory conditions.

The content of Tl in Haplic Chernozem before pollution was $0.98 \mathrm{mg} / \mathrm{kg}$. Soil $(1 \mathrm{~kg})$ was incubated in plastic vessels in triplicate at room temperature $\left(20-22^{\circ} \mathrm{C}\right)$ and optimal moistening (25\% of water field capacity) and soil density $\left(1.2 \mathrm{~g} / \mathrm{cm}^{3}\right)$. The frequency of assessment of biological activity of Haplic Chernozem was 10, 30 and 90 days after contamination.

\subsection{Determination of Biological Indicators}

The total number of bacteria, Azotobacter spp. abundance, activity of catalase and dehydrogenases, and phytotoxic properties (the germination rate of radish seeds) of soil were determined. The total number of bacteria in the soil was measured using luminescent microscopy and Azotobacter spp. abundance by the number of lumps fouling in the Ashby medium. The number of soil bacteria was determined by the luminescence microscopy method while considering the number of soil bacteria after staining with acridine orange [44]. The results were expressed in $10^{9}$ bacteria in $1 \mathrm{~g}$ of soil (Equation (1)):

$$
\mathrm{M}=\frac{4 \times \mathrm{A} \times \mathrm{H} \times 10^{10}}{\mathrm{P}}
$$

where $\mathrm{M}$-number of cells per $1 \mathrm{~g}$ of soil; $\mathrm{A}$-the average number of cells within one field of vision; $\mathrm{H}$-dilution index; and $\mathrm{P}$ - the area of the field of vision in $\mu \mathrm{m}^{2}$.

The enzyme activities such as catalase were determined by the decomposition rate of $\mathrm{H}_{2} \mathrm{O}_{2}$, and dehydrogenases by the rate of conversion of triphenyltetrazolium chloride (TPC) into triphenylformazan (TPF). The activities of catalase and dehydrogenases, total number of bacteria, length of roots, and germination rate of the radish seeds were summed $[45,46]$. Thereafter, the average assessment point of studied indices was calculated for each variant using Equation (2):

$$
\mathrm{B}=\frac{\mathrm{B}_{1}+\mathrm{B}_{2}+\ldots+\mathrm{B}_{\mathrm{n}}}{\mathrm{N}}
$$

where $B$-average estimated score of indicators; $B_{1} \ldots . B_{n}$-the relative score of the indicator; and $\mathrm{N}$ - the number of indicators.

The integral index of the soil biological state (IIBS) was calculated using Equation (3):

$$
\text { IIBS }=\frac{B}{B_{\max }} \times 100 \%
$$


where $B$ - the average estimated score of all indicators; and $B_{\max }$ - the maximum estimated score of all indicators.

Soil phytotoxicity was investigated by the germination rate of radish in moisture conditions of $25 \%$ and temperature conditions of $24-25^{\circ} \mathrm{C}$ in the growth chamber after 7 days (Binder KBW 240).

The indices of the intensity of the initial growth of the radish seeds (length of radish shoots and roots) were calculated as the average of the triplicates [44]. The indicator of seed germination rate was calculated using Equation (4):

$$
\mathrm{G}=\frac{\mathrm{n}_{1}+\mathrm{n}_{2 \ldots}}{2}
$$

where $\mathrm{G}$-seed germination; $\mathrm{n}_{1}$-number of the seed of 1st replicate; $\mathrm{n}_{2}$-number of the seed of 2 nd replicate and so on.

For the calculation of IIBS, the value of each of the above indicators on the control was taken as $100 \%$. The percentages in other experimental variants (in polluted soil) were expressed as a percentage relative to the control. For the IIBS condition, a maximum value of each index $(100 \%)$ was chosen from the array data, and approximately this value of the index was expressed for other variants of experiments using Equation (5):

$$
\mathrm{B}_{1}=\frac{\mathrm{B}_{\mathrm{x}}}{\mathrm{B}_{\max }} \times 100 \%
$$

where $B_{1}$-the relative score of the indicator; $B_{x}$-the actual value of the indicator; and $\mathrm{B}_{\max }$ - the maximum value of the indicator.

The activities of catalase and dehydrogenases indicated the potential biological activity of the soil. Based on the results of determining the biological parameters, the IIBS of the soil was calculated [47]. During diagnostics of contamination value of each index in noncontaminated soil, it was taken as $100 \%$. With reference to its value, the same index in the contaminated soil was expressed in percent. The obtained IIBS value was expressed as a percentage with respect to the control (to 100\%). The methodology used allowed the integration of the relative values of different indicators, which ordinarily cannot be integrated since they have different units of measurement.

\subsection{Statistical Analyses}

An analysis of variance (ANOVA) was carried out to check the reliability of the results, followed by the determination of the least significant difference (LSD) at $p \leq 0.05$. Data are means of triplicate biological samples. Statistical data processing was carried out using Statistica 12.0 and Python 3.6.5 Matpolib package.

\section{Results}

\subsection{Influence of Thallium on Microbiological Indices}

The results of the influence of $\mathrm{Tl}$ at different concentrations $(3,30$ and $300 \mathrm{mg} / \mathrm{kg})$ on the total number of bacteria in Haplic Chernozem after 10,30 and 90 days of pollution are shown in Figure 2A. Doses of $3 \mathrm{mg} / \mathrm{kg}$ caused a significant $(p<0.05)$ decrease in the total number of bacteria by 46,40 and 39\% compared to the control for 10, 30 and 90 days of pollution, respectively. The inhibition of the total number of bacteria was observed at 61 , 63 and $56 \%$ relative to the control when $\mathrm{Tl}$ was introduced into the soil in the amount of $30 \mathrm{mg} / \mathrm{kg}(p<0.05)$. Similarly, the total number of bacteria decreased by $68-76 \%$ relative to the control values at $300 \mathrm{mg} / \mathrm{kg}(p<0.05)$. The results of the influence of the $\mathrm{Tl}$ in the studied concentrations $(3,30$ and $300 \mathrm{mg} / \mathrm{kg}$ ) on the Azotobacter spp. abundance are shown in Figure 2B. The statistically reliable decrease in the Azotobacter spp. abundance was observed in the soil contaminated by Tl in the amount of $3 \mathrm{mg} / \mathrm{kg}(p<0.05)$. The percent decline caused by the $3 \mathrm{mg} / \mathrm{kg}$ of Tl was 16, 18 and 19\% after 10, 30 and 90 days of pollution, respectively. The inhibition of Azotobacter spp. abundance was observed at 27, 21 and $26 \%$ relative to the control when $\mathrm{Tl}$ was introduced into the soil in the amount of 
$30 \mathrm{mg} / \mathrm{kg}(p<0.05)$. The Azotobacter spp. abundance decreased by $36-40 \%$ relative to the control values at $300 \mathrm{mg} / \mathrm{kg}(p<0.05)$.

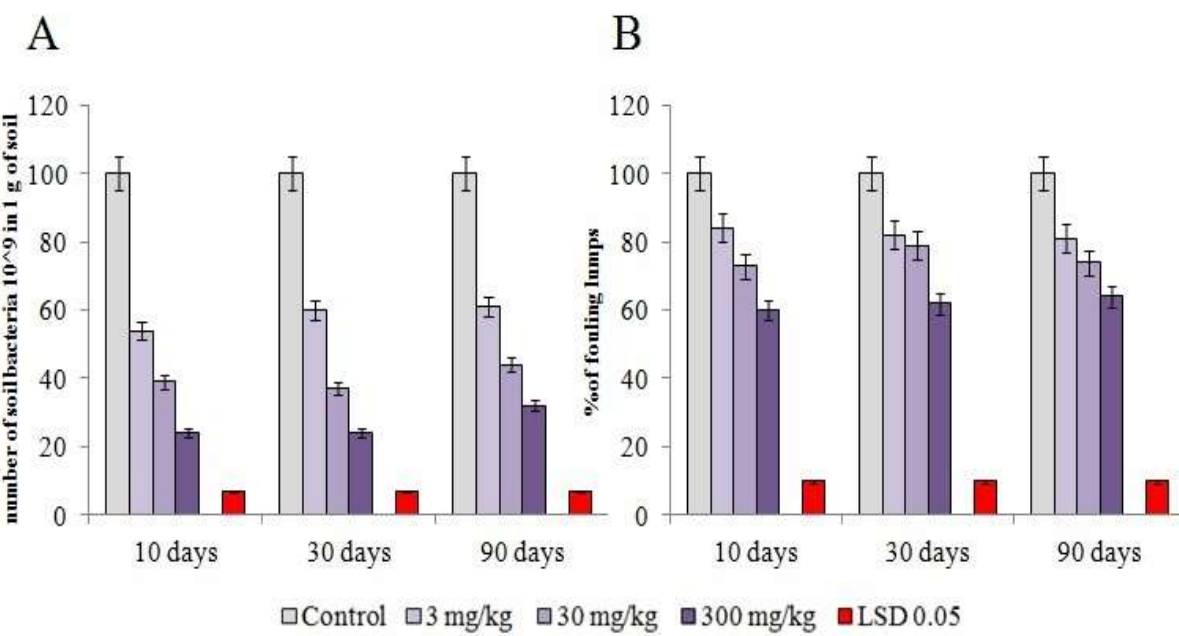

Figure 2. Effects of thallium on microbiological properties of Haplic Chernozem after 10, 30, and 90 days (\% of control): (A) the total number of bacteria; (B) Azotobacter spp. abundance.

\subsection{Influence of Thallium on the Activity of Enzymes of Soil}

Enzymatic activities (catalase and dehydrogenases) of Haplic Chernozem after $\mathrm{Tl}$ pollution were altered (Figure 3). The results of the influence of the $\mathrm{Tl}$ at the studied concentrations $(3,30$ and $300 \mathrm{mg} / \mathrm{kg})$ on the activity of catalase of Haplic Chernozem are shown in Figure 3A. Thallium in the amount of $30 \mathrm{mg} / \mathrm{kg}$ caused a decrease in the catalase activity by 19,12 and $16 \%(p<0.05)$ with respect to the control for 10,30 and 90 days of exposure. Likewise, the decline in the activity of catalase ranged from $61-65 \%$ relative to the control at $300 \mathrm{mg} / \mathrm{kg}$.

A

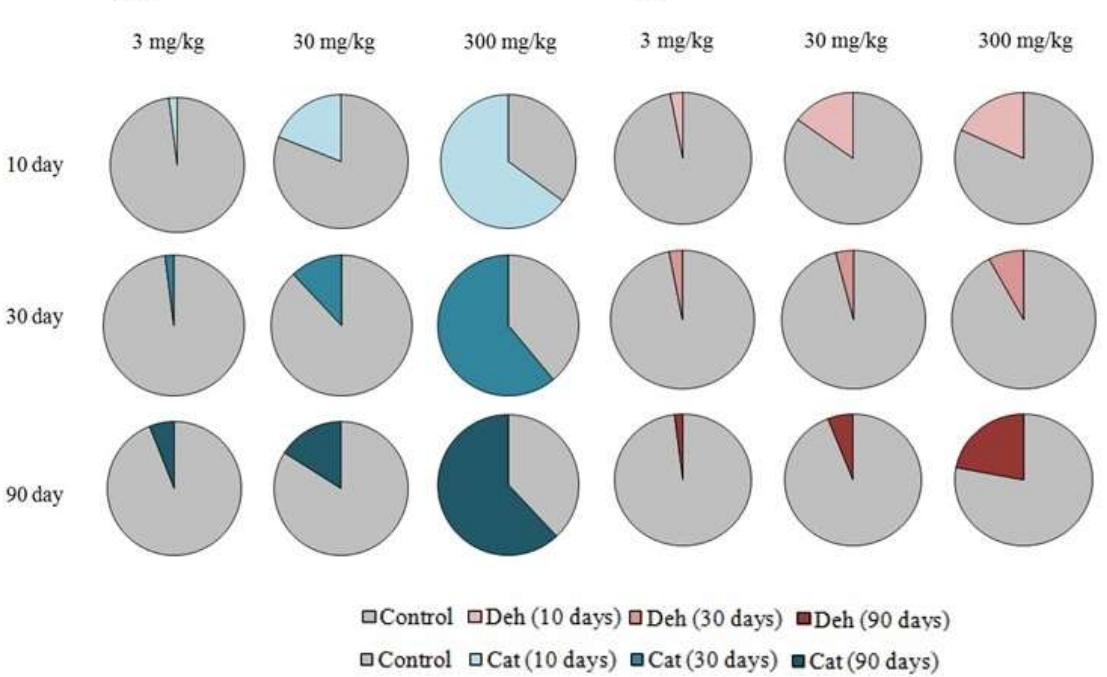

Figure 3. Effects of thallium on the enzymatic activity of Haplic Chernozem after 10, 30 and 90 days (\% of control): (A) activity of catalase (Cat in legend); (B) activity of dehydrogenases (Deh in legend).

Figure 3B shows the results of the influence of $\mathrm{Tl}$ at concentrations of 3, 30 and $300 \mathrm{mg} / \mathrm{kg}$ on the activity of dehydrogenases in the Haplic Chernozem. The Tl at $30 \mathrm{mg} / \mathrm{kg}$ for 10 days of exposure caused a decrease in dehydrogenase activity by $15 \%(p<0.05)$ relative to the control. The activity of dehydrogenases at $300 \mathrm{mg} / \mathrm{kg}$ decreased by 18 and $22 \%(p<0.05)$ in comparison to the control after 10 and 90 days of exposure, respectively. 


\subsection{Influence of Thallium on the Germination Rate of Radish}

The results of the influence of the $\mathrm{Tl}$ at the studied concentrations $(3,30$ and $300 \mathrm{mg} / \mathrm{kg})$ on the radish germination rate are shown in Figure 4. A statistically unreliable stimulating effect of $\mathrm{Tl}$ at the concentrations of 3 and $30 \mathrm{mg} / \mathrm{kg}$ on the radish germination rate was recorded. At such doses of pollution by $\mathrm{Tl}$, disturbances in the growth and development of radish were not found. A dose of $300 \mathrm{mg} / \mathrm{kg}$ of Tl inhibited seed germination by 17 and $19 \%$ as compared to the control for 10 and 30 days of exposure, respectively.

10 day

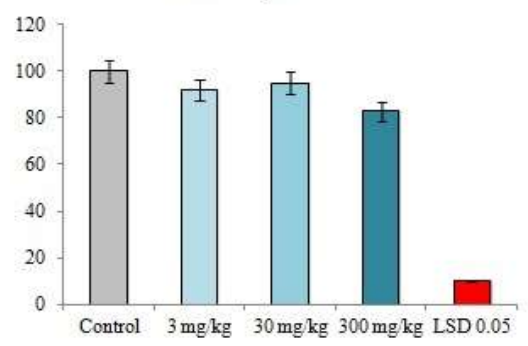

30 day

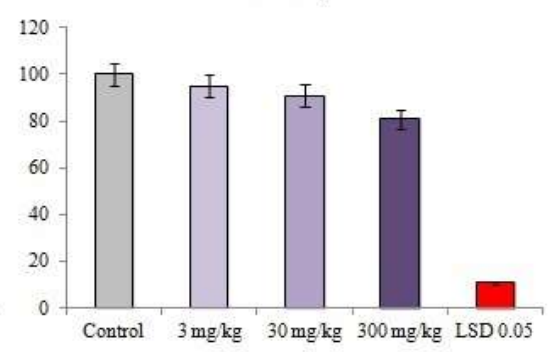

90 day

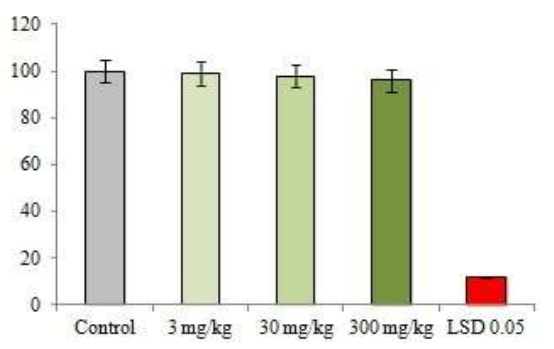

Figure 4. Effects of thallium on germination rate of radish in Haplic Chernozem after 10, 30 and 90 days ( $\%$ of control).

\subsection{Integrated Index of the Biological State of Soil Contaminated with Thallium}

The enzymes of the class of oxidoreductases (activity of catalase and dehydrogenases) were more sensitive to chemical pollution than other classes of enzymes. Figure 5 shows the results of the influence of Tl at the concentrations of 3,30 and $300 \mathrm{mg} / \mathrm{kg}$ on IIBS in Haplic Chernozem after 10, 30 and 90 days of contamination. Tl in the concentration of $3 \mathrm{mg} / \mathrm{kg}$ caused a significant decrease in the indicator by 15,14 and $13 \%(p<0.05)$ after 10 , 30 and 90 days relative to the control. The Tl decreased IIBS at the $30 \mathrm{mg} / \mathrm{kg}$ concentration by 21,22 , and $25 \%(p<0.05)$ after 10,30 and 90 days of treatment relative to the control. A dose of $300 \mathrm{mg} / \mathrm{kg}$ of Tl reduced IIBS by 43, 40, and 38\% after 10, 30 and 90 days, relative to control values. Thus, the degree of reduction was observed to be dose-dependent, and also relied on the exposure period of $\mathrm{Tl}$ contamination. When Haplic Chernozem was polluted with $\mathrm{Tl}$, the degree of decrease in the biological properties of the soil directly depended on its concentration in the soil. This pattern was noted in most cases. A month after the pollution of Haplic Chernozem with Tl, the biological properties of the soil were subjected to the strongest negative influence. The biological indicators of Tl-contaminated Haplic Chernozem showed a tendency to recovery three months after incubation. Nevertheless, the biological activity of Haplic Chernozem, even after 90 days, did not reach the value of uncontaminated soil (Table 1). 


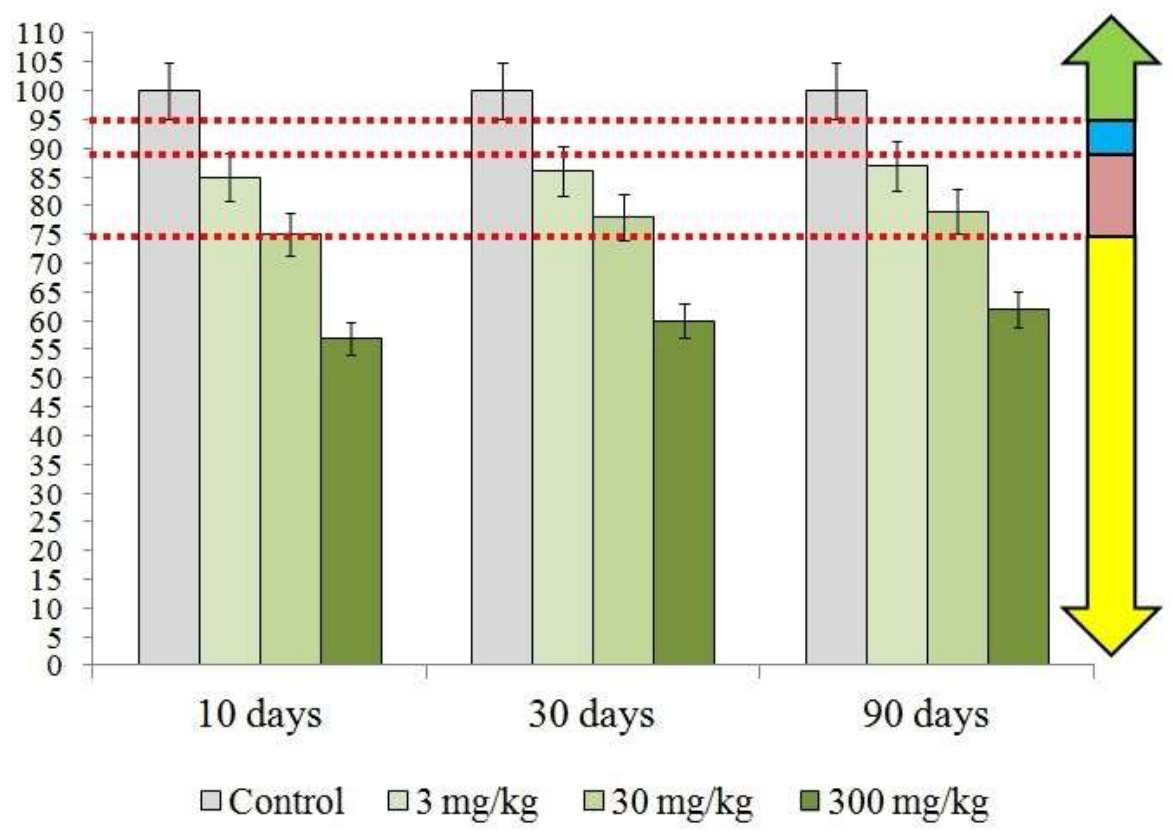

\begin{tabular}{|c|c|l|}
\hline Color & IIBS, \% & Disturbed ecosystem functions \\
\hline & $>25 \%$ & Physical functions \\
\hline & $10-25 \%$ & Chemical, physical and biochemical functions \\
\hline & $5-10 \%$ & Informational functions \\
\hline & $<5 \%$ & - \\
\hline
\end{tabular}

Figure 5. Effects of thallium pollution on the Integrated Index of Biological State (IIBS) of Haplic Chernozem after 10,30, and 90 days (\% of control).

Table 1. Assessment of biological indicators of Haplic Chernozem conditions contaminated with thallium by sensitivity and informativeness.

\begin{tabular}{|c|c|c|}
\hline Indicator & Degree of Sensitivity ${ }^{1}$ & Informative Value ${ }^{2}$ \\
\hline Number of soil bacteria & 57 & -0.70 \\
\hline Azotobacter spp. abundance & 59 & -0.83 \\
\hline Activity of catalase & 88 & -0.90 \\
\hline Activity of dehydrogenases & 79 & -0.88 \\
\hline Germination rate of radish & 93 & -0.94 \\
\hline IIBS & 75 & -0.87 \\
\hline
\end{tabular}

${ }^{1}$ Sensitivity of the biological indicator as the intensity of the decrease in the biological indicator of Haplic Chernozem contaminated by $\mathrm{Tl}, \%$ of uncontaminated soil (average values are indicated for doses and incubation periods). ${ }^{2}$ The informative value of the indicator is the correlation coefficient (r) between the amount of thallium in Haplic Chernozem and the biological indicators $(p=0.05)$.

In order to use biological indicators for monitoring and diagnostics of soils contaminated by $\mathrm{Tl}$, as well as for standardizing the $\mathrm{Tl}$ content in soils and terrestrial ecosystems, it was necessary to assess the degree of sensitivity and information content of these indicators. The degree of sensitivity of biological indicators was assessed by the intensity of their decrease when polluted with various concentrations of $\mathrm{Tl}$ relative to values in uncontaminated soil. The degree of information content of biological indicators in the contamination of Haplic Chernozem with $\mathrm{Tl}$ was assessed by the tightness of the correlation between the indicator and the amount of the polluting element in the soil.

Several biological indicators reflecting the degree of their sensitivity (Table 1) by $\mathrm{Tl}$ contamination had the following sequence (the \% changes in the indicator relative to the control are in parentheses):

Number of soil bacteria (57) $\geq$ Azotobacter spp. abundance (59) $\geq$ activity of dehydrogenases (79) $>$ activity of catalase (88) > germination rate (93). 
Biological indicators for pollution of Haplic Chernozem with $\mathrm{Tl}$ in terms of the degree of information content were arranged in the following order, as described in Table 1:

Germination rate $(-0.94)>$ activity of catalase $(-0.90)>$ activity of dehydrogenases $(-0.88)$ $>$ Azotobacter spp. abundance $(-0.83)>$ number of soil bacteria $(-0.70)$.

The greatest sensitivity to $\mathrm{Tl}$ pollution was shown by the total number of soil bacteria and the Azotobacter spp. abundance belonging to the group of microbiological indicators. The most informative indicators for pollution of Haplic Chernozem with $\mathrm{Tl}$ are enzymes belonging to the class of oxidoreductases (catalase and dehydrogenases) and phytotoxicity indicators (radish seed germination). In addition to $\mathrm{Tl}$, similar patterns apply to most heavy metals and metalloids. The choice of biological indicators for assessing the state of soil when contaminated with $\mathrm{Tl}$ was due to the following reasons. The total number of bacteria in the soil characterizes the state of the destructors in the ecosystem. Azotobacter spp. abundance is traditionally used as an indicator for assessing the ecotoxicity of chemical elements for the soil. The activity of catalase and dehydrogenases reflects the intensity of mineralization processes in the soil. Among the enzymes, oxidoreductases are the most sensitive to chemical contamination.

\section{Discussion}

At a low level of soil pollution with $\mathrm{Tl}$, in isolated cases, statistically insignificant stimulating effects of biological activity were noted $[6,9,18,48,49]$. Statistically insignificant stimulation of the Azotobacter spp. abundance trended toward increase in significance with an increasing dose up to $300 \mathrm{mg} / \mathrm{kg}$ and duration of Tl exposure up to 90 days. When the soil was contaminated with $\mathrm{Tl}$, the nitrogen balance in the soil did not change, and therefore, Azotobacter spp. abundance in the soil depended little on the concentration and duration of $\mathrm{Tl}$ exposure [50]. For radish germination, recovery was noted with an increase in exposure to 90 days. This was probably due to the adaptation and transition of $\mathrm{Tl}$ to the vegetative parts of the plant [51,52]. A decrease in the permeability of biological membranes, inhibition of enzymes, and, as a result, metabolic disorders, were consequences of the toxic effect of $\mathrm{Tl}$ on the biological activity of soils, as well as plants [15,53]. The concentration of the pollutant in the soil determines the sequence of violations of the ecological functions of the soil: first of all, informational, then biochemical, physicochemical, chemical, integral, and then physical.

The soil IIBS is a well-recognized indicator that depicts a disturbance in ecosystem functions. A decrease in IIBS by less than $5 \%$ reflects no disturbance in the ecosystem functions. However, a decrease in the value of IIBS by more than $5 \%$ shows disturbed functioning in an ecosystem; e.g., a decrease of $5-10 \%$ means a violation of informational functions; of $10-25 \%$ leads to biochemical, physicochemical, chemical, and integral dysfunction; and of more than $25 \%$ is associated with physical properties [47]. Serious disturbances in the functioning of soils caused by $\mathrm{Tl}$ contamination were diagnosed when the integral indicator of the IIBS decreased by more than $10 \%$. The concentration of $\mathrm{Tl}$ causing such a decrease can be considered the maximum permissible concentration (MPC) of this element in the soil. Based on the regression equations, it is possible to calculate the dependence of the degree of decrease in IIBS values on the concentration of $\mathrm{Tl}$ in the soil. The level of decrease in IIBS values, depending on the Tl content, determines the order of the disturbance of the ecosystem functions of the soil that occurred [47]. At a minimum concentration, a violation of information functions occurs, and further with an increase in the content of a pollutant of biochemical, physicochemical, chemical, and integral dysfunction; and at maximum, physical functions. Thallium concentrations calculated using the regression equations causing a violation of certain ecological functions are presented in Table 2. 
Table 2. Environmental regulation (for MPC) of thallium pollution of Haplic Chernozem by the degree of violation of ecosystem functions.

\begin{tabular}{|c|c|c|c|c|}
\hline \multirow{2}{*}{ Properties } & \multicolumn{4}{|c|}{ Degree of Violation of Ecosystem Functions } \\
\hline & Minimal & Slight & Moderate & Maximal \\
\hline $\begin{array}{c}\text { Degree } \\
\text { of soil IIBS } \\
\text { reduction }{ }^{1}\end{array}$ & $<5 \%$ & $5-10 \%$ & $10-25 \%$ & $>25 \%$ \\
\hline $\begin{array}{l}\text { Violated } \\
\text { ecosystem } \\
\text { functions }^{2}\end{array}$ & - & Informational & $\begin{array}{c}\text { Chemical, } \\
\text { physico- } \\
\text { chemical, } \\
\text { biochemical, } \\
\text { holistic }\end{array}$ & Physics \\
\hline $\begin{array}{c}\text { Thallium } \\
\text { content, } \mathrm{mg} / \mathrm{kg}\end{array}$ & $<1.4$ & $1.4-2.5$ & $2.5-20$ & $>20$ \\
\hline $\begin{array}{l}\text { Soil remediation } \\
\text { methods }\end{array}$ & Not required & Phytoremediation & $\begin{array}{l}\text { Chemical } \\
\text { reclamation }\end{array}$ & $\begin{array}{c}\text { Removing } \\
\text { contaminated } \\
\text { soil }\end{array}$ \\
\hline
\end{tabular}

Note: ${ }^{1}$ determination of IIBS of soils according to Kolesnikov et al. [47]. ${ }^{2}$ Classification of ecosystem functions of soil.

According to Table 2, rationing of soils contaminated with $\mathrm{Tl}$ is directly related to the violation of the ecological functions of the soil. If the concentration of $\mathrm{Tl}$ does not exceed $0.5 \mathrm{mg} / \mathrm{kg}$, there is no disruption of the soil's ecological activities. The information functions of soil contaminated with $\mathrm{Tl}$ were documented to be disturbed when its concentration ranged from 1.5 to $4.4 \mathrm{mg} / \mathrm{kg}$. If the concentration of $\mathrm{Tl}$ in the soil is from 4.4 to $106.0 \mathrm{mg} / \mathrm{kg}$, then the chemical, physico-chemical, and integral functions of the soil will be violated. The physical functions of the soil will be impaired if the $\mathrm{Tl}$ concentration exceeds $106.0 \mathrm{mg} / \mathrm{kg}$. Thus, violation of integral functions in soil contamination with $\mathrm{Tl}$ has serious consequences for soil fertility.

Thallium concentration of $4.4 \mathrm{mg} / \mathrm{kg}$ in Haplic Chernozem causing a violation of integral functions can be considered the MPC. When carrying out a wide range of environmental activities aimed at assessing the impact of $\mathrm{Tl}$ on the environment, monitoring soils and terrestrial ecosystems contaminated with $\mathrm{Tl}$, and choosing methods for restoring Tl-contaminated soils. The MPCs for Tl developed in this work can be used to normalize soil pollution. Soils of different regions of the world, similar to Haplic Chernozem in terms of resistance to heavy metal pollution [54,55], can be normalized using the MPC of Tl in the soil established as per this work, which was $4.4 \mathrm{mg} / \mathrm{kg}$. Soils were similar in the terms of stability, and had a similar grain size composition, $\mathrm{pH}$, and soil organic matter content [31]. Methods for the restoration of Tl-contaminated soils, depending on the concentration that had the highest efficiency, are presented in Table 2. Reorganization of Haplic Chernozem is not required if the concentration of $\mathrm{Tl}$ in the soil does not exceed $0.5 \mathrm{mg} / \mathrm{kg}$.

It seems promising to continue studies of the toxic effects of $\mathrm{Tl}$ on the ecological state of soils in the following directions: an intensive assessment of the ecotoxicity of different doses of $\mathrm{Tl}$ in soils from the background concentration up to $20,000 \mathrm{mg} / \mathrm{kg}$; to determine the toxicity of different chemical forms of $\mathrm{Tl}$ for soil; to study changes in soil properties under Tl pollution with dynamics (from 10 to 360 days); to study a wider range of biological indicators of soil contamination with $\mathrm{Tl}$; and to investigate the joint effect of $\mathrm{Tl}$ polluted with complicated other pollutants in order to identify synergistic and antagonistic effects in relation to soil properties. The relationships between $\mathrm{Tl}$ and microbial communities in soil with different Tl-contamination levels were noted [56]. The toxic effects of $\mathrm{Tl}$ on soil biological properties and its accumulation in plant tissues were also observed by several researchers $[16,57,58]$. 


\section{Conclusions}

According to the results of the present study, it was found that when Haplic Chernozem was contaminated with $\mathrm{Tl}$, for all biological indicators, the maximal significant impact was observed on the total number of soil bacteria; i.e., Azotobacter spp. abundance and catalase activity, while a less obvious toxic effect of $\mathrm{Tl}$ was noticeable in relation to the activity of dehydrogenases and a phytotoxical indicator (the germination rate of radish seeds). The highest sensitivity to $\mathrm{Tl}$ contamination was established by the number of soil bacteria. However, at low $\mathrm{Tl}$ concentrations, there was no significant difference from the control in terms of the activity of dehydrogenases and the germination rate of radish seeds. The IIBS, which characterized the state of the soil biota, varied from 13 to $43 \%$ depending on the $\mathrm{Tl}$ concentration. We concluded that the results showed toxic effects of $\mathrm{Tl}$ on the compositions of soil bacterial communities and enzyme activity.

Author Contributions: Conceptualization, S.K., T.M. (Tatiana Minnikova), N.T., E.N., Y.A. and K.K.; methodology, S.K. and T.T.-M.; software, S.K. and T.M. (Tatiana Minnikova); validation, S.K., T.M. (Tatiana Minnikova), S.M., S.S. and T.M. (Tatiana Minkina); formal analysis, N.T.; resources, S.K., K.K. and I.A.; writing-original draft preparation, S.K., T.M. (Tatiana Minkina), V.P., A.Z., A.T. and I.A.; writing-review and editing, V.D.R.; visualization, T.M. (Tatiana Minkina); supervision, T.M. (Tatiana Minkina) and S.M.; project administration, V.D.R.; funding acquisition, A.R., S.K., A.Z. and T.M. (Tatiana Minkina). All authors have read and agreed to the published version of the manuscript.

Funding: This research received no external funding.

Acknowledgments: The research was financially supported by the Ministry of Science and Higher Education of the Russian Federation project on the development of the Young Scientist Laboratory (no. LabNOTs-21-01AB) and the Higher Scientific School of the Russian Federation (no. SSc-2511.2020.11).

Conflicts of Interest: The authors declare that they have no competing interests.

\section{References}

1. Minnikova, T.; Kolesnikov, S.; Minkina, T.; Mandzhieva, S. Assessment of Ecological Condition of Haplic Chernozem Calcic Contaminated with Petroleum Hydrocarbons during Application of Bioremediation Agents of Various Natures. Land 2021, 10, 169. [CrossRef]

2. Sushkova, S.; Minkina, T.; Deryabkina, I.; Rajput, V.; Antonenko, E.; Nazarenko, O.; Yadav, B.K.; Hakki, E.; Mohan, D. Environmental pollution of soil with PAHs in energy producing plants zone. Sci. Total. Environ. 2018, 655, 232-241. [CrossRef]

3. Chaplygin, V.A.; Rajput, V.D.; Mandzhieva, S.S.; Minkina, T.M.; Nevidomskaya, D.G.; Nazarenko, O.G.; Kalinitchenko, V.P.; Singh, R.; Maksimov, A.Y.; Popova, V.A. Comparison of Heavy Metal Content in Artemisia austriaca in Various Impact Zones. ACS Omega 2020, 5, 23393-23400. [CrossRef] [PubMed]

4. Minnikova, T.; Denisova, T.; Mandzhieva, S.; Kolesnikov, S.; Minkina, T.; Chaplygin, V.; Burachevskaya, M.; Sushkova, S.; Bauer, T. Assessing the effect of heavy metals from the Novocherkassk power station emissions on the biological activity of soils in the adjacent areas. J. Geochem. Explor. 2016, 174, 70-78. [CrossRef]

5. Minkina, T.M.; Motuzova, G.V.; Mandzhieva, S.; Nazarenko, O.G.; Burachevskaya, M.; Antonenko, E.M. Fractional and group composition of the $\mathrm{Mn}, \mathrm{Cr}, \mathrm{Ni}$, and $\mathrm{Cd}$ compounds in the soils of technogenic landscapes in the impact zone of the Novocherkassk Power Station. Eurasian Soil Sci. 2013, 46, 375-385. [CrossRef]

6. Xiao, E.; Ning, Z.; Sun, W.; Jiang, S.; Fan, W.; Ma, L.; Xiao, T. Thallium shifts the bacterial and fungal community structures in thallium mine waste rocks. Environ. Pollut. 2020, 268, 115834. [CrossRef]

7. Nriagu, J.O.; Pacyna, J.M. Quantitative assessment of worldwide contamination of air, water and soils by trace metals. Nature 1988, 333, 134-139. [CrossRef] [PubMed]

8. Liu, J.; Luo, X.; Sun, Y.; Tsang, D.; Qi, J.; Zhang, W.; Li, N.; Yin, M.; Wang, J.; Lippold, H.; et al. Thallium pollution in China and removal technologies for waters: A review. Environ. Int. 2019, 126, 771-790. [CrossRef]

9. D’Orazio, M.; Campanella, B.; Bramanti, E.; Ghezzi, L.; Onor, M.; Vianello, G.; Vittori-Antisari, L.; Petrini, R. Thallium pollution in water, soils and plants from a past-mining site of Tuscany: Sources, transfer processes and toxicity. J. Geochem. Explor. 2019, 209, 106434. [CrossRef]

10. Belzile, N.; Chen, Y. Thallium in the environment: A critical review focused on natural waters, soils, sediments and airborne particles. Appl. Geochem. 2017, 84, 218-243. [CrossRef]

11. Karbowska, B. Presence of thallium in the environment: Sources of contaminations, distribution and monitoring methods. Environ. Monit. Assess. 2016, 188, 1-19. [CrossRef] [PubMed]

12. Vodyanitskii, Y.N. Contamination of soils with heavy metals and metalloids and its ecological hazard (analytic review). Eurasian Soil Sci. 2013, 46, 793-801. [CrossRef] 
13. Lin, H.; Liu, C.; Li, B.; Dong, Y. Trifolium repens L. regulated phytoremediation of heavy metal contaminated soil by promoting soil enzyme activities and beneficial rhizosphere associated microorganisms. J. Hazard. Mater. 2020, 402, 123829. [CrossRef]

14. Wang, Y.; Zhou, Y.; Wei, X.; Chen, Y.; Beiyuan, J.; She, J.; Wang, L.; Liu, J.; Liu, Y.; Wang, J.; et al. Effects of thallium exposure on intestinal microbial community and organ functions in zebrafish (Danio rerio). Elem. Sci. Anthr. 2021, 9, 00092. [CrossRef]

15. Mazur, R.; Sadowska, M.; Kowalewska, Ł.; Abratowska, A.; Kalaji, H.M.; Mostowska, A.; Garstka, M.; Krasnodębska-Ostręga, B. Overlapping toxic effect of long term thallium exposure on white mustard (Sinapis alba L.) photosynthetic activity. BMC Plant Biol. 2016, 16, 191. [CrossRef] [PubMed]

16. Peter, A.J.; Viraraghavan, T. Thallium: A review of public health and environmental concerns. Environ. Int. 2005, 31, 493-501. [CrossRef]

17. Campanella, B.; Casiot, C.; Onor, M.; Perotti, M.; Petrini, R.; Bramanti, E. Thallium release from acid mine drainages: Speciation in river and tap water from Valdicastello mining district (northwest Tuscany). Talanta 2017, 171, 255-261. [CrossRef]

18. Liu, J.; Ren, S.; Zhou, Y.; Tsang, D.C.; Lippold, H.; Wang, J.; Yin, M.; Xiao, T.; Luo, X.; Chen, Y. High contamination risks of thallium and associated metal(loid)s in fluvial sediments from a steel-making area and implications for environmental management. J. Environ. Manag. 2019, 250, 109513. [CrossRef] [PubMed]

19. Liu, J.; Wang, J.; Chen, Y.; Shen, C.-C.; Jiang, X.; Xie, X.; Chen, D.; Lippold, H.; Wang, C. Thallium dispersal and contamination in surface sediments from South China and its source identification. Environ. Pollut. 2016, 213, 878-887. [CrossRef]

20. Jia, Y.; Xiao, T.; Zhou, G.; Ning, Z. Thallium at the interface of soil and green cabbage (Brassica oleracea L. var. capitata L.): Soil-plant transfer and influencing factors. Sci. Total. Environ. 2013, 450-451, 140-147. [CrossRef]

21. Xiao, T.; Yang, F.; Li, S.; Zheng, B.; Ning, Z. Thallium pollution in China: A geo-environmental perspective. Sci. Total. Environ. 2012, 421-422, 51-58. [CrossRef] [PubMed]

22. Bačeva, K.; Stafilov, T.; Šajn, R.; Tănăselia, C.; Makreski, P. Distribution of chemical elements in soils and stream sediments in the area of abandoned Sb-As-Tl Allchar mine, Republic of Macedonia. Environ. Res. 2014, 133, 77-89. [CrossRef]

23. Grösslová, Z.; Vaněk, A.; Oborná, V.; Mihaljevic, M.; Ettler, V.; Trubac, J.; Drahota, P.; Penížek, V.; Pavlů, L.; Sracek, O.; et al. Thallium contamination of desert soil in Namibia: Chemical, mineralogical and isotopic insights. Environ. Pollut. 2018, 239, 272-280. [CrossRef]

24. Pavoni, E.; Petranich, E.; Adami, G.; Baracchini, E.; Crosera, M.; Emili, A.; Lenaz, D.; Higueras, P.; Covelli, S. Bioaccumulation of thallium and other trace metals in Biscutella laevigata nearby a decommissioned zinc-lead mine (Northeastern Italian Alps). J. Environ. Manag. 2017, 186, 214-224. [CrossRef]

25. Liu, J.; Wang, J.; Xiao, T.; Bao, Z.; Lippold, H.; Luo, X.; Yin, M.; Ren, J.; Chen, Y.; Linghu, W. Geochemical dispersal of thallium and accompanying metals in sediment profiles from a smelter-impacted area in South China. Appl. Geochem. 2018, 88, 239-246. [CrossRef]

26. Kolesnikov, S.I.; Tsepina, N.I.; Sudina, L.; Minnikova, T.V.; Kazeev, K.S.; Akimenko, Y.V. Silver Ecotoxicity Estimation by the Soil State Biological Indicators. Appl. Environ. Soil Sci. 2020, 2020, 1-9. [CrossRef]

27. McFeters, G.A.; Yu, F.P.; Pyle, B.H.; Stewart, P. Physiological assessment of bacteria using fluorochromes. J. Microbiol. Methods 1995, 21, 1-13. [CrossRef]

28. Val'kov, V.F.; Kolesnikov, S.I.; Kazeev, K.S.; Tashchiev, S.S. Influence of heavy metal pollution on microscopic fungi and Azotobacter of common chernozem. Russ. J. Ecol. 1997, 28, 345-346.

29. Liu, Y.; Zeng, G.; Zhong, H.; Wang, Z.; Liu, Z.; Cheng, M.; Liu, G.; Yang, X.; Liu, S. Effect of rhamnolipid solubilization on hexadecane bioavailability: Enhancement or reduction? J. Hazard. Mater. 2017, 322, 394-401. [CrossRef] [PubMed]

30. Kaczynski, P.; Łozowicka, B.; Hrynko, I.; Wołejko, E. Behaviour of mesotrione in maize and soil system and its influence on soil dehydrogenase activity. Sci. Total Environ. 2016, 571, 1079-1088. [CrossRef]

31. Kolesnikov, S.I.; Yaroslavtsev, M.V.; Spivakova, N.A.; Kazeev, K. Comparative assessment of the biological tolerance of chernozems in the south of Russia towards contamination with $\mathrm{Cr}, \mathrm{Cu}, \mathrm{Ni}$, and Pb in a model experiment. Eurasian Soil Sci. 2013, 46, 176-181. [CrossRef]

32. Kolesnikov, S.; Tsepina, N.; Minnikova, T.; Kazeev, K.; Mandzhieva, S.; Sushkova, S.; Minkina, T.; Mazarji, M.; Singh, R.; Rajput, V. Influence of Silver Nanoparticles on the Biological Indicators of Haplic Chernozem. Plants 2021, 10, 1022. [CrossRef] [PubMed]

33. Stpniewska, Z.; Wolińska, A.; Ziomek, J. Response of soil catalase activity to chromium contamination. J. Environ. Sci. 2009, 21, 1142-1147. [CrossRef]

34. Pandey, S.N. Accumulation heavy metals (cadmium, cromium, copper, nickel and zinc) in Raphanus salivus L. and Spinacia olerac L. Plants Irrigated with Industrial Effluents. J. Environ. Biol. 2006, 27, 381-384.

35. Kolesnikov, S.I.; Zharkova, M.G.; Kazeev, K.; Kutuzova, I.V.; Samokhvalova, L.S.; Naleta, E.V.; Zubkov, D.A. Ecotoxicity assessment of heavy metals and crude oil based on biological characteristics of chernozem. Russ. J. Ecol. 2014, 45, 157-166. [CrossRef]

36. Plekhanova, I.O.; Zolotareva, O.A.; Tarasenko, I.D.; Yakovlev, A.S. Assessment of ecotoxicity of soils contaminated by heavy metals. Eurasian Soil Sci. 2019, 52, 1274-1288. [CrossRef]

37. Nikolaeva, O.V.; Terekhova, V.A. Improvement of laboratory phytotest for the ecological evaluation of soils. Eurasian Soil Sci. 2017, 50, 1105-1114. [CrossRef]

38. Aponte, H.; Meli, P.; Butler, B.; Paolini, J.; Matus, F.; Merino, C.; Cornejo, P.; Kuzyakov, Y. Meta-analysis of heavy metal effects on soil enzyme activities. Sci. Total. Environ. 2020, 737, 139744. [CrossRef] 
39. Gorbov, S.N.; Gorovtsov, A.V.; Bezuglova, O.S.; Anisimova, M.A.; Skripnikov, P.N.; Tishchenko, S.A.; Marschner, B. Enzyme activity of soils in urban landscapes of the lower Don area, Southern Russia. Land Degrad. Dev. 2020, 32, 1618-1631. [CrossRef]

40. Mandzhieva, S.S.; Goncharova, L.Y.; Batukaev, A.A.; Minkina, T.M.; Bauer, T.V.; Shertnev, A.K.; Chaplygin, V.A.; Sushkova, S.N.; Poluektov, E.V.; Burachevskaya, M.V.; et al. Current State of Haplic Chernozems in Specially Protected Natural Areas of the Steppe Zone. Online J. Biol. Sci. 2017, 17, 363-371. [CrossRef]

41. Chernova, O.V.; Bezuglova, O.S. Principles and Features of the Compilation of the Red Data Book of Soils of the Steppe Regions (on Example of the Rostov Oblast). Arid. Ecosyst. 2018, 8, 28-37. [CrossRef]

42. Ralph, L.; Twiss, M.R. Comparative toxicity of thallium(I), thallium(III), and cadmium(II) to the unicellular alga Chlorella isolated from Lake Erie. Bull. Environ. Contam. Toxicol. 2002, 68, 261-268. [CrossRef] [PubMed]

43. Lan, C.-H.; Lin, T.-S. Acute toxicity of trivalent thallium compounds to Daphnia magna. Ecotoxicol. Environ. Saf. 2005, 61, 432-435. [CrossRef]

44. Kazeev, K.S.; Kolesnikov, S.I.; Akimenko, Y.V.; Dadenko, E.V. Metody Biodiagnostiki Nazemnyh Ekosistem; Publishing House SFedU: Rostov-on-Don, Russia, 2016; 356p.

45. Galstyan, A.S. Unification of methods for studying the activity of soil enzymes. Eurasian Soil Sci. 1978, 2, 107-114.

46. Nannipieri, P.; Giagnoni, L.; Renella, G.; Puglisi, E.; Ceccanti, B.; Masciandaro, G.; Fornasier, F.; Moscatelli, M.C.; Marinari, S. Soil enzymology: Classical and molecular approaches. Biol. Fertil. Soils 2012, 48, 743-762. [CrossRef]

47. Kolesnikov, S.I.; Kazeev, K.S.; Akimenko, Y.V. Development of regional standards for pollutants in the soil using biological parameters. Environ. Monit. Assess. 2019, 191, 1-10. [CrossRef]

48. Wick, S.; Baeyens, B.; Fernandes, M.M.; Göttlicher, J.; Fischer, M.; Pfenninger, N.; Plötze, M.; Voegelin, A. Thallium sorption and speciation in soils: Role of micaceous clay minerals and manganese oxides. Geochim. Cosmochim. Acta 2020, 288, 83-100. [CrossRef]

49. Xiao, T.; Guha, J.; Boyle, D.; Liu, C.-Q.; Chen, J. Environmental concerns related to high thallium levels in soils and thallium uptake by plants in southwest Guizhou, China. Sci. Total. Environ. 2004, 318, 223-244. [CrossRef]

50. Aasfar, A.; Bargaz, A.; Yaakoubi, K.; Hilali, A.; Bennis, I.; Zeroual, Y.; Kadmiri, I.M. Nitrogen Fixing Azotobacter Species as Potential Soil Biological Enhancers for Crop Nutrition and Yield Stability. Front. Microbiol. 2021, 12. [CrossRef] [PubMed]

51. Loria, A.; Cristescu, M.E.; Gonzalez, A. Mixed evidence for adaptation to environmental pollution. Evol. Appl. 2019, 12, 1259-1273. [CrossRef]

52. Minkina, T.; Fedorenko, G.; Nevidomskaya, D.; Konstantinova, E.; Pol'Shina, T.; Fedorenko, A.; Chaplygin, V.; Mandzhieva, S.; Dudnikova, T.; Hassan, T. The Morphological and Functional Organization of Cattails Typha laxmannii Lepech. and Typha australis Schum. and Thonn. under Soil Pollution by Potentially Toxic Elements. Water 2021, 13, 227. [CrossRef]

53. Sharma, R.; Agrawal, M. Biological effects of heavy metals: An overview. J. Environ. Biol. 2005, 26, 301-313. [PubMed]

54. Lukin, S.V.; Selyukova, S.V. Ecological Assessment of the Content of Cadmium in Soils and Crops in Southwestern Regions of the Central Chernozemic Zone, Russia. Eurasian Soil Sci. 2018, 51, 1547-1553. [CrossRef]

55. Srivastava, V.; Sarkar, A.; Singh, S.; Singh, P.; Araujo, A.; Singh, R.P. Agroecological Responses of Heavy Metal Pollution with Special Emphasis on Soil Health and Plant Performances. Front. Environ. Sci. 2017, 5. [CrossRef]

56. She, J.; Liu, J.; He, H.; Zhang, Q.; Lin, Y.; Wang, J.; Yin, M.; Wang, L.; Wei, X.; Huang, Y.; et al. Microbial response and adaption to thallium contamination in soil profiles. J. Hazard. Mater. 2021, 423, 127080. [CrossRef] [PubMed]

57. Al-Najar, H.; Kaschl, A.; Schulz, R.; Römheld, V. Effect of thallium fractions in the soil and pollution origins on tl uptake by hyperaccumulator plants: A key factor for the assessment of phytoextraction. Int. J. Phytoremediat. 2005, 7, 55-67. [CrossRef] [PubMed]

58. Lacoste, C.; Robinson, B.; Brooks, R. Uptake of thallium by vegetables: Its significance for human health, phytoremediation, and phytomining. J. Plant Nutr. 2001, 24, 1205-1215. [CrossRef] 